\title{
Mikrovyučování jako prostor pro implementaci vrstevnického hodnocení do přípravy studentů učitelství $^{1}$
}

\author{
Lukáš Rokos \\ Jihočeská univerzita v Českých Budějovicích, Pedagogická fakulta, Katedra biologie
}

Redakci zasláno 21.11. 2019 / upravená verze obdržena 6.10. 2020 /

/ k uveřejnění přijato 6. 10. 2020

\begin{abstract}
Abstrakt: Příspěvek propojuje dva fenomény přípravy studentů učitelství. Jedním z nich je užití mikrovyučování při oborových didaktikách a druhým je užití vrstevnického hodnocení. V rámci mikrovyučování při didaktice př́rodopisu a biologie si 66 studentů učitelství navzájem hodnotilo svůj výkon. Nástrojem, který jim k tomu pomáhal, byl strukturovaný hodnoticí formulář obsahující pět škálových položek a tři otevřené položky. Ukázalo se, že studenti učitelství nemají problém hodnotit na škálových položkách, ale slovní zpětnou vazbu poskytují již méně ochotně. $\mathrm{Z}$ analýzy poskytnutých zpětných vazeb bylo zjištěno, že nejčastěji se hodnotitelé zaměřili na jazykový projev studenta, způsob aktivizace a probuzení zájmu žáka o učivo. Dále si všímali vhodnosti navržené aktivity k věku žáků. Pozitivním zjištěním byl fakt, že se ve zpětné vazbě nijak neprojevovaly osobní vztahy mezi studenty. Komentáře s formativním charakterem se ve zpětné vazbě př́liš často nevyskytovaly, ale v případě, že hodnotitel poskytl formativní zpětnou vazbu, tak byla správná a poskytovala hodnocenému studentovi důležitou informaci.
\end{abstract}

Klíčová slova: mikrovyučování, formativní hodnocení, vrstevnické hodnocení, zpětná vazba, příprava učitelů, studenti učitelství

\section{Př́íprava učitelů}

V centru pozornosti $\mathrm{v}$ rámci pregraduální přípravy učitelů stojí praktická výuka na školách v podobě průběžné či souvislé praxe. Počet hodin, který je této př́ípravě věnován v profesní př́ípravě studentů učitelství, je ale nedostatečný, popřípadě není efektivně využitý (Švec, 2005; Vítečková, 2019). Ne vždy je však konkrétní počet hodin strávených na školách jediným faktorem,

1 Př́spěvek vznikl za finanční podpory projektu Grantové agentury Jihočeské univerzity v Českých Budějovicích (GAJU 123/2019/S). Autor by rád touto cestou vyjádřil poděkování oběma anonymním recenzentům za velmi podnětné připomínky a doporučení na doplnění původního rukopisu. 
který způsobuje to, že praxe není dostačující. Problémy související s pedagogickou praxí je možné rozdělit do šesti oblastí (Rokos, Vančura, \& Procházka, 2019; Žlábková, Procházka, \& Vítečková, 2016): (1) nevyhovující provázání teoretických předmětů na fakultách připravujících učitele a problémů vyplývajících z pedagogické praxe; (2) nejednotná podoba průběžné praxe na jednotlivých katedrách či fakultách ve smyslu lišícího se zadání, způsobu realizace a zejména reflexe a vyhodnocení, které vede k nedostatečnému využití zjištěných pedagogických situací ve výuce na fakultě; (3) nejednotný pohled na kompetence, kterými by měl být vybaven absolvent pedagogické fakulty, včetně způsobu jejich rozvoje během studia; (4) chybějící možnosti pro sdílení zkušeností studentů učitelství, vysokoškolských učitelů a učitelů z (fakultních) škol; (5) nedostatečná podpora popularizačních akcí, při nichž by studenti učitelství mohli realizovat vlastní nápady a rozšířit si pedagogické zkušenosti; (6) odtržení tematického zaměření pedagogických výzkumů od skutečných potřeb škol a pedagogických pracovníků.

Zmíněná nedostatečná hodinová dotace průběžných praxí studentů učitelství a problémy spojené s její samotnou realizací jsou výraznými limity efektivnější přípravy studentů učitelství. Praxe se často omezuje jen na tři kroky - příprava, realizace a evaluace, přičemž poslední krok je pouze rychlý a často mu chybí systematičnost (Procházka, Vítečková, \& Žlábková, 2015). Stále také chybí promyšlenější propojení předmětů obecné didaktiky, oborových didaktik a dalších předmětů pedagogicko-psychologického základu (Žlábková, Procházka, \& Vítečková, 2016; Procházka, Vítečková, \& Žlábková, 2015).

Spilková s kolektivem (2004) zdůrazňuje, že studenty učitelství je nutné připravovat na nové pojetí jejich profese, zejména ve smyslu osvojení si kompetencí souvisejících s novými koncepcemi výuky. A nové koncepce stále přibývají, zatímco pregraduální př́íprava učitelů na tyto změny reaguje pomalu. Didaktici na fakultách připravujících učitele se většinou snaží o rozššřrení pedagogické praxe i jinými způsoby - např́iklad pořádáním popularizačních akcí, do kterých jsou studenti učitelství aktivně zapojeni, nebo „trénováním“ výuky v simulovaných podmínkách na fakultě. Ve druhém př́ípadě se již dlouhou dobu setkáme s mikrovyučovaním jako součástí pregraduální přípravy studentů učitelství. 


\section{Mikrovyučování v přípravě studentů učitelství}

Mikrovyučování studentů učitelství je vzhledem k výše zmíněným nedostatkům $\mathrm{v}$ průběžné praxi zásadním prvkem $\mathrm{v}$ přípravě a nácviku profesních dovedností. Mikrovyučování se $\mathrm{v}$ přípravě učitelů začalo používat $\mathrm{v}$ roce 1963 (Allen \& Ryan, 1969), kdy tým výzkumníků na Stanford University ve Spojených státech tento přístup zkoušel $\mathrm{v}$ rámci projektu zaměřeného na rozvoj profesních dovedností učitelů a pojem microteaching zavedl. $V$ tomto projektu se výzkumníci soustředili na využití videozáznamů výuky k diskuzi o výkonu daného učitele a možnostech pozměnit následující hodinu tak, aby byla efektivnější ve vztahu k dosažení výukového cíle. Prakticky byl celý projekt založen na následujících krocích: výuka - zpětná vazba a rozbor hodiny (s využitím videa) - přeplánování (na základě rozboru bylo rozhodnuto, co je vhodné opakovat, a co nikoliv) - výuka podle nového schématu - nová zpětná vazba a rozbor (opět s využitím videa). Allen a Ryan (1969) definovali základní charakteristické rysy mikrovyučování následovně: (1) jedná se o reálnou výukovou situaci; (2) umožňuje snížit vliv některých faktorů, které by užití daných metod či forem omezovaly - například ve vztahu k počtu žáků, množství času, obsahu učiva, které je nutné žákům předat, apod.; (3) podporuje osvojení si pestrého množství výukových aktivit a dovedností (napřr. metod či forem výuky) a učí budoucí učitele provést vhodný výběr obsahu předávaného učiva; (4) umožňuje lepší kontrolu nad aktivitami, protože většina faktorů, které se v simulovaném prostředí objevují, může být pozměněna tak, aby konkrétní faktory měly na danou aktivitu větší dopad a ve výsledku byla celá realizace mikrovyučování efektivnější; (5) významně rozšiřuje možnost poskytnutí zpětné vazby, protože každý student mủže okamžitě obdržet zpětnou vazbu na svůj výkon od didaktika či svých vrstevníků; (6) umožňuje využít různé techniky k reflexi, například audio- či videonahrávky, záznamové archy apod. Důležitými faktory pro realizaci mikrovyučování jsou jeho délka, ideálně navrhovaná v rozmezí 10-20 minut, a počet zapojených studentů, který by se měl pohybovat od 10 do 30 (Bakir, 2014). Počet studentů blížící se třiceti účastníkům do jisté míry odpovídá velikosti školní tř́dy, čímž lze zajistit určitou autenticitu daného prostředí.

V českých podmínkách je mikrovyučování zařazováno do takzvaných pedagogických intervencí, které mají významný vliv na utváření didaktických dovedností při seminářích v rámci přípravy studentů učitelství (Šmahelová, 2005). Švec (2000) definuje pedagogickou intervenci jako „systematický postup učitele, který u studentů navozuje a do určité míry reguluje proces 
osvojování pedagogických dovedností, přičemž tento postup poskytuje prostor pro autoregulaci jejich učení (Švec, 2000, s. 83). Skalková (2007) zařazuje mikrovyučování mezi inscenační metody jako specifickou inscenaci částí vyučovacího procesu. Problematice mikrovyučování a jejích proměn a posunu v takzvanou mikrovýstupovou praxi se věnuje Svatoš (1997a), který vyzdvihuje mikrovyučování jako příležitost pro studenty jednat v simulované a reflektované situaci. Zároveň označuje mikrovýstup za základní prvek mikrovyučování. Svatoš (1997a) odvozuje mikrovýstupovou praxi od činnostního a dovednostního modelu př́ípravy učitelů a popisuje některé z jejích klíčových aspektů: etapizaci profesionalizačního děje, gradaci profesionalizačních etap (Spilková, 1995), individuální zaměřenost přípravy (Svatoš, 1997b), celistvější př́ístup k posuzování minulé činnosti a koncepci budoucího jednání. Horká (1997) se zaměřila přímo na studenty učitelství, kteří mikrovyučování realizovali v rámci své př́ípravy, a sledovala, jaké zkušenosti a názory měli studenti po praktické realizaci aktivit. Zjistila, že studenti byli schopni hodnotit některé své kompetence, hledali pozitiva i negativa na svých výkonech a uvědomovali si úskalí spojená s užitím různých výukových metod či forem (Horká, 1997). Z posledních studií se na využití mikrovyučování ve spojení s dialogickým vyučováním zaměřil Sucháček (2016), který sledoval, zda studenti učitelství dokáží užívat principy dialogického vyučování při mikrovyučování přírodovědných předmětů.

Pokud bychom shrnuli výše uvedené informace, tak mikrovyučování je tradičním a bezpochyby vhodným prostředkem $\mathrm{v}$ přípravě budoucích učitelů, protože jim umožňuje vyzkoušet si výukové aktivity pod dohledem didaktika a simulovat různé situace, které by mohly v reálné výuce ve škole nastat (Bakir, 2014). Další nespornou výhodou je obdržení zpětné vazby na výkon (Benton-Kupper, 2001), čímž mikrovyučování představuje i vhodný prostor pro implementaci formativního hodnocení.

\section{Formativní hodnocení a vrstevnické hodnocení}

Formativní hodnocení je v současné době hojně propagovaným trendem, avšak lze říci, že se nejedná o nový přístup, jelikož učitelé prvky formativního hodnocení běžně v praxi využívají. Často si však své praktiky nespojují s tímto moderním termínem.

Formativní hodnocení je založeno na poskytnutí zpětné vazby v době, kdy žák může svůj výkon ještě změnit či vylepšit (Berry, 2008; Koenig, 2011; Pasch et 
al., 2005). Jeho hlavním účelem je diagnostikovat potíže žáků v procesu učení, čímž může usnadnit jejich nápravu (Wiliam \& Leahy, 2015). Jak uvádějí Starý a Laufková (2016), tak při formativním hodnocení nestačí rozlišovat, jestli je daný žák horší či lepší, ale poskytnout mu informaci, co se naučil, co se ještě naučit může a jak může lépe dosáhnout vytyčeného cíle. Yorke (2005a) zdůrazňuje význam formativního hodnocení i ve vztahu k zaměstnanosti, jelikož lepší porozumění žáků a studentů konkrétním specifikům oborů a kompetencím s nimi spojeným (například sociální práce, vzdělávání, zdravotnictví) jsou běžně očekávanou prerekvizitou při přijímání do práce. Právě u oborů, které požadují specifické kompetence, je příprava budoucích zaměstnanců náročnější a často vyžaduje i praxi, při níž je formativní hodnocení ideální cestou, kterou mohou studenti získat zpětnou vazbu na svůj výkon a dále se rozvíjet (Yorke, 2005a). Zpětná vazba je jedním z nejvýznamnějších faktorů, které mohou ovlivnit proces učení se (Butler \& Winne, 1995), a je prokázán její významný dopad na žákovo či studentovo učení a dosažené výsledky (Hattie \& Timperley, 2007).

Zpětná vazba představuje klíčový prvek formativního hodnocení a její význam v procesu učení je velmi dobře zdokumentován (např. Sadler, 2010; Gibbs \& Simpson, 2004). K tomu dodávají Boud a Molloy (2013), že nelze pozorovat efekt v procesu učení se, pokud se v něm aspoň v nějaké podobě nevyskytuje zpětná vazba. Nicméně, zcela zásadním aspektem je, aby si poskytování zpětné vazby mohli vyzkoušet samotní aktéři vzdělávacího procesu (Ducasse \& Hill, 2019). Yorke (2005b) rozděluje zpětnou vazbu na formální a neformální a popisuje různé osoby, od kterých tyto dva typy zpětné vazby může student či žák obdržet (viz Tab. 1). Knight a Yorke (2003) však zdůrazňují, že se jedná o velmi komplexní proces, ve kterém je velký prostor k tomu, aby došlo k chybnému pochopení zpětné vazby či rozvoji miskoncepcí. 
Tabulka 1

Zdroje formální a neformální zpětné vazby (převzato a přeloženo z Yorke, 2005b)

\begin{tabular}{|c|c|c|}
\hline Zpětná vazba & Formální & Neformální \\
\hline Od učitele & $\begin{array}{l}\text { nejspíše nejčastější a běžně } \\
\text { používaný prístup ve vzdělávání }\end{array}$ & $\begin{array}{l}\text { často ve specifických podmínkách } \\
\text { (např. laboratorní práce, exkurze...) }\end{array}$ \\
\hline Od vrstevníků & $\begin{array}{l}\text { užití při aktivitách zaměřených } \\
\text { na vrstevnické hodnocení }\end{array}$ & $\begin{array}{l}\text { diskuze mezi žáky či kolegy } \\
\text { o přestávce či pauze na kávu }\end{array}$ \\
\hline Od ostatních & $\begin{array}{l}\text { při praxi či odborném výcviku } \\
\text { (hodnotitelem je mentor či učitel } \\
\text { z praxe) }\end{array}$ & $\begin{array}{l}\text { pravděpodobně hlavní přístup } \\
\text { v kontextu praktické přípravy } \\
\text { pro budoucí profesi }\end{array}$ \\
\hline $\begin{array}{l}\text { Od sebe } \\
\text { samého }\end{array}$ & $\begin{array}{l}\text { v případech, kdy to formát hodnocení } \\
\text { vyžaduje - v některých případech } \\
\text { pevná součást vzdělávání }\end{array}$ & $\begin{array}{l}\text { když je student či žák schopen se } \\
\text { dívat na svůj výkon sebekriticky }\end{array}$ \\
\hline
\end{tabular}

Boud a Molloy (2013) přinášejí zajímavé rozlišení dvou modelů zpětné vazby. První, který lze označit za tradiční, staví do centra učitele, který nejen zpětnou vazbu poskytuje, ale zároveň rozhoduje o tom, zda došlo k pokroku, či nikoliv. Andrade (2010) popisuje postupný posun učitele z centra dění a přenos zodpovědnosti i na další aktéry. Popis tohoto modelu se shoduje s definicí od Hendersona a kolektivu (2018), kteří vymezují zpětnou vazbu jako proces, ve kterém žáci chápou smysl informací vztahujících se k jejich výkonu a užívají je k tomu, aby zlepšili svou práci i své učební strategie. Podle této definice by zpětná vazba měla mířit na rozvoj žákových učebních strategií a učení se jako takového. Nicméně i v tomto prŕípadě žák potřebuje určité dovednosti, aby dokázal se zpětnou vazbu pracovat a byl schopen využít její potenciál (Pandero, Andrade, \& Brookhart, 2018). Tyto kompetence může získat zejména tak, že do hodnocení bude aktivně zapojovat.

Cantillon a Sargeant (2008) propagují tzv. reflektivní zpětnovazebnou diskuzi, v níž dochází k poskytování zpětné vazby formou dialogu mezi žáky a učitelem a mezi žáky navzájem. Autoři dodávají, že tento způsob podporuje schopnost hodnotit vlastní aktivitu a vede k sdílenému pohledu na to, co je potřeba vylepšit (Cantillon \& Sargeant, 2008).

\subsection{Vrstevnické hodnocení}

V tomto př́ispěvku se více zaměřím na vrstevnické hodnocení, které je jednou z metod formativního hodnocení, při níž žáci navzájem sdílejí své hodnoticí 
výroky a pomáhají si tak vzájemně prohloubit porozumění dané problematice (Sivan, 2010; Vickerman, 2009). Vrstevnické hodnocení žákům poskytuje příležitost rozšíríit si vlastní schopnosti i další výhody. Výzkumy zaměřené na tento způsob hodnocení ve výuce ukazují, že zapojení žáků do této aktivity zvyšuje efektivitu formativního hodnocení obecně a podporuje učební procesy a jejich výstupy (Dijks, Brummer, \& Kostons, 2018; Liu et al., 2001; Lu \& Bol, 2007).

Žáci považují vrstevnické hodnocení za nápomocnější a pochopitelnější než hodnocení od učitele, zejména z důvodu použití př́istupnějšího jazyka (Gibbs \& Simpson, 2004; Nicol, Thomson, \& Breslin, 2014). Ačkoliv učitelé poskytují zpětnou vazbu na základě svých vlastních zkušeností a zaměřují se na klíčové body v procesu učení, často je tato zpětná vazba pro žáky psána komplikovaně (Mathan \& Koedinger, 2005) či se zaměřuje na př́liš obecné dovednosti žáků, které se snaží rozvíjet, tudíž může hodnocenému žákovi připadat značně abstraktní (Metcalfe \& Kornell, 2007).

V některých př́padech je vhodné podpořit proces hodnocení strukturovaným hodnoticím nástrojem, který hodnotitele vede k zaměření na klíčové aspekty výkonu svého vrstevníka (Panadero, Romero, \& Strijbos, 2013). Je požadováno, aby hodnotitel měl určitou úroveň znalostí ve vztahu k oboru a obsahu (Mathan \& Koedinger, 2005; Geithner \& Pollastro, 2016) i ve vztahu k daným aktivitám (Cho \& MacArthur, 2011). Zároveň by však žáci, kteří poskytují zpětnou vazbu svým spolužákům, měli mít pocit autonomie. To znamená, že učitel by neměl kontrolovat, jak kvalitní vazbu poskytují, a opravovat jim jednotlivá tvrzení. Na druhou stranu by však měl být připravený pomoci, pokud si jeho asistenci hodnotitel vyžádá (Miao, Badger, \& Zhen, 2006).

Dalším významným faktorem, který ovlivňuje proces vrstevnického hodnocení, je sociální interakce mezi žáky. Žáci jsou vědomě nebo i nevědomě ovlivněni vztahy mezi sebou, vlastnostmi spolužáků a osobními postoji a preferencemi (Lu \& Bol, 2007; Raes, Vanderhoven, \& Schellens, 2015), což může snížit kvalitu i užitečnost poskytnuté zpětné vazby. Mnoho žáků se obává použití zpětné vazby, protože v porovnání se zpětnou vazbou od učitele její správnostinevěří. Stejně tak se hodnotící žák může obávat napsat komentář svému spolužákovi, protože si není jistý svými znalostmi a nechce mu špatně poradit. Některým žákům také vadí představa, že jejich práci uvidí spolužáci a následně ji budou i hodnotit (Raes, Vanderhoven, \& Schellens, 2015). Pokud je však nastoleno vhodné třídní klima, tak může mít proces vrstevnického hodnocení pozitivní dopad nejen na obsahovou stránku předkládané práce 
žáků (Govaerts et al., 2011), ale také na míru přijetí zpětné vazby a úroveň zpětné vazby poskytnuté (Strijbos, Narciss, \& Dünnerbier, 2010). Jak dodávají zmínění autoři, pozitivní tlak na hodnotícího žáka může vést $\mathrm{k}$ tomu, že se snaží svým spolužákům pomoci a poskytnout co nejlepší rady.

Žáci často hodnocení vnímají odlišně než učitelé a promítají do něj jiné pohledy (Andon, Dewey, \& Leung, 2017) a obecně mohou divergentně chápat účel zpětné vazby (Weaver, 2006) nebo mají nedostatek zkušeností k tomu, aby zpětnou vazbu kvalitně formulovali či adekvátně využili (Gibbs, 2010; Johnsson, 2013; Poulos \& Mahony, 2008). Price s kolektivem (2010) dodávají, že efektivita zpětné vazby je často limitována tím, že si žáci veškeré komentáře čtou pouze povrchně, pokud tak vůbec učiní. Tento fakt se prokázal i v projektu ASSIST-ME (Assess Inquiry in Science, Technology and Mathematics Education). Ve zmíněném výzkumu se žáci na druhém stupni nejdříve zaměřili na obdrženou sumativní známku a slovní komentáře poté procházeli pouze $\mathrm{v}$ rychlosti. Ačkoliv $\mathrm{v}$ rozhovorech uváděli, že komentáře pečlivě pročetli a pracovali s nimi, realita zjištěná z videonahrávek a pozorování výzkumníků př́mo při hodině byla odlišná (Le Hebel et al., 2018).

Fakt, že přijetí vrstevnické zpětné vazby se u jednotlivých žáků liší, není nijak překvapující, jelikož různí hodnotitelé samožrejmě poskytují různě kvalitní zpětnou vazbu, tudíž i posouzení její vhodnosti a př́nosnosti je u hodnocených žáků odlišné. Přijetí zpětné vazby je ovlivněno tedy nejen hodnotitelem a jeho zkušenostmi či znalostmi, ale také osobním postojem hodnoceného žáka (Evans, 2013). Obecně je zpětná vazba od žáka s lepšími učebními výsledky považována za efektivnější než od žáka s horšími studijními výsledky. Na tom samozřejmě také není nic překvapivého, avšak ve vztahu k praktickým činnostem je možné, že žák s horšími studijními výsledky bude schopen poradit ve smyslu realizace pokusu a jeho praktického provedení lépe než žák, který má vynikající teoretické znalosti (Strijbos, Narciss, \& Dünnebier, 2010). I z tohoto důvodu je vhodné, aby se do procesu vrstevnického hodnocení zapojovali všichni žáci. Výhodné je nechat žáky poskytovat zpětnou vazbu ve dvojicích, kde se nad ní mohou např́íklad poradit a prodiskutovat možná řešení dané úlohy (Rokos \& Lišková, 2019).

Promítnutí sociálních vztahů do poskytnuté zpětné vazby a vůbec jejich dopad na proces vrstevnického hodnocení lze snížit užitím anonymní zpětné vazby (Lu \& Bol, 2007). Dojde tak k podpoření ochoty žáků zapojit se do procesu a ke zredukování nejistoty či stresu spojených s tím, že se hodnocený 
žák dozví, kdo mu zpětnou vazbu napsal (Vickerman, 2009; van Gennip, Segers, \& Tillema, 2010). Tím se zvýší i víra v sebe sama a žáci poskytují zpětnou vazbu otevřeněji a bez obav, což často vede i ke zvýšení kvality poskytnutých komentářo (Rotsaert et al., 2017). Tento fakt potvrdil i výzkum Dijkse a kolektivu (2018), kteří zjistili, že existuje pozitivní vztah mezi zkušenostmi hodnotitele a vnímáním užitečnosti zpětné vazby. Zpětná vazba v anonymním procesu hodnocení byla následně ze strany hodnocených žáků více akceptována (Dijks et al., 2018).

Hodnoticí schopnosti žáků je možné zvýšit tak, že jim budou zcela jasně prezentována hodnoticí kritéria, a to nejen při vrstevnickém hodnocení. Stejným způsobem lze zvýšit i míru přijetí zpětné vazby ze strany hodnoceného žáka (Cho \& MacArthur, 2011; Meusen-Beekman, Josten-ten Brinke, \& Boshuizen, 2015). Učitel by se měl vyhnout tomu, aby kritéria hodnocení př́liš zobecňoval. Je lepší ilustrovat jednotlivá kritéria hodnocení pomocí konkrétních příkladů (Cho \& MacArthur, 2011).

Prezentované informace se vztahují zejména k žákům na základních a středních školách, ale ukazuje se, že stejné obtíže mají i studenti učitelství připravující se na vysoké škole (Ducasse \& Hill, 2019). Z tohoto důvodu je nutné začlenit poskytování zpětné vazby do přípravy učitelů, aby se s tímto způsobem setkali a sami na sobě si ho vyzkoušeli ještě v pregraduální přípravě. Mnohem snáze jej pak mohli aplikovat do vlastní praxe ataké být schopni identifikovat problémy související s užitím tohoto přístupu. Právě vlastní zkušenost s tímto procesem může pomoci zaměřit se na klíčové aspekty při představování vrstevnického hodnocení nebo sebehodnocení žákům při vlastní výuce.

\section{$4 \quad$ Cíl studie}

Cílem této studie bylo vyhodnocení, do jaké míry je formativní vrstevnické hodnocení vhodným způsobem evaluace mikrovyučování realizovaného při pregraduální přípravě učitelů přírodopisu a biologie. Na základě literárních zdrojů byl vytvořen hodnoticí formulář pro studenty, jenž byl následně analyzován. $\mathrm{V}$ rámci výzkumu jsme si stanovili následující výzkumné otázky:

1) Do jaké míry jsou studenti učitelství schopni poskytnout zpětnou vazbu na výkon svých vrstevníků?

2) Budou studenti učitelství ochotněji hodnotit pomocí škálové stupnice, nebo pomocí slovních komentářů u otevřených položek? 
3) Objeví se ve slovních komentářích formativní hodnocení?²

4) Na jaké aspekty se zaměří hod notitelé ve své zpětné vazbě? Promítnou do svého hodnocení subjektivní názory či emoce?

\section{Metodologie výzkumu}

Mikrovýstupy byly realizovány se studenty učitelství přírodopisu pro základní školy $(\mathrm{N}=47)$ připravující se na Pedagogické fakultě Jihočeské univerzity v Českých Budějovicích a se studenty učitelství biologie pro střední školu ( $\mathrm{N}=19)$ studující na Přírodovědecké fakultě stejné univerzity. Všichni zapojení studenti byli v době realizace studie v prvním ročníku navazujícího magisterského studia. Praktické výstupy studentů proběhly v rámci předmětu didaktika př́rodopisu II, resp. didaktika biologie II, v letním semestru $\mathrm{v}$ roce 2018 a 2019 . Z hlediska pohlaví byly v souboru zastoupeny více ženy $(\mathrm{N}=56)$ než muži $(\mathrm{N}=10)$.

V rámci zmíněných předmětů si každý student vylosoval vyučovací metodu, kterou měl následně formou mikrovyučování na libovolné téma představit ostatním. Délka mikrovyučování musela být v rozmezí 10-15 minut. Po skončení aktivního výstupu proběhlo anonymní vrstevnické hodnocení. Pro vrstevnické hodnocení byl využit strukturovaný hodnoticí formulář, na jehož vyplnění měli hodnotitelé vždy 10 minut. Celkem bylo tímto způsobem získáno 807 hodnoticích formulářù, které byly následně převedeny do digitální formy v programu MS Excel. Student, který vedl výuku, obdržel zpět anonymizované shrnutí všech vrstevnických hodnocení. Tento souhrn byl doplněn i stručným písemným hodnocením vyučujícího daného předmětu. Vždy po procesu vrstevnického hodnocení proběhlo ještě zhodnocení výstupu ústní formou, prostřednictvím malého kolokvia, kdy nejdříve student, který aktivně výstup realizoval, zhodnotil samostatně svůj výkon (sebehodnocení) a následovaly komentáře od vrstevníkủ a vyučujícího. Jevilo se jako důležité, aby tento proces proběhl až po poskytnutí písemné vrstevnické zpětné vazby, jelikož by hodnotitelé byli určitě ovlivněni tím, co v diskuzi slyšeli.

Z mikrovyučování každý student následně zpracoval dle vzorové šablony prezentaci a do této prezentace reflektoval i obdrženou zpětnou vazbu. Všechny prezentace byly umístěny do prostředí Moodle, odkud si je mohli ostatní studenti kompletně stáhnout pro případné použití ve své praxi.

2 Tím je myšleno, zda bude komentář obsahovat zmínku o tom, co skutečně změnit, aby př́íště mikrovýstup dopadl lépe a přiblížil se vytyčenému vzdělávacímu cíli. 


\subsection{Hodnoticí formulár}

Jak již bylo výše zmíněno, pro poskytování zpětné vazby byl použit strukturovaný hodnoticí formulár. Vzhledem k tomu, že studenti neměli př́liš velké zkušenosti s procesem vrstevnického hodnocení, jevil se tento formulář jako vhodná opora při poskytování zpětné vazby. První část formuláře obsahovala předepsaných pět oblastí, které se vztahovaly ke kvalitě mikrovyučování: (1) atraktivita (např. aktivizace, motivační prvky); (2) zpracování (např. adekvátnost věku, názornost); (3) správnost (např. věcná správnost); (4) kvalita projevu (např logika mluveného slova, vyjadřování se) a (5) využitelnost v praxi. U této části měli hodnotitelé za úkol zvolit své hodnocení na škále od 1 do 10 , kdy číslo 10 představovalo nejlepší hodnocení. Ve druhé části formuláře byly tři otevřené položky, u kterých se nejprve hodnotitel vyjadřoval k silným stránkám výstupu, poté k slabým stránkám, a nakonec mohl navrhnout změny, které by bylo vhodné ve výstupu udělat. $\mathrm{V}$ úvodním semináři byla účastníkům představena podoba formuláře a bylo s nimi diskutováno porozumění jednotlivým oblastem včetně kritérií, která by ve svém hodnocení měli užívat (viz příklady uvedené v závorkách výše). $V$ případě, že si studenti nedovedli představit konkrétní kritérium, byl uveden i ilustrativní příklad, jak by mohl být komentář př́ípadně formulován.

\subsection{Vyhodnocení dat}

První část formuláře byla vyhodnocena kvantitativně a byly porovnávány průměry hodnocení ve vztahu k jednotlivým oblastem a pak i průměry hodnocení celého výstupu. Průměry byly zvoleny záměrně, jelikož se lišil počet hodnotitelů u jednotlivých výstupů, takže totální součty by nebyly relevantním ukazatelem.

Druhá část obsahovala již zmíněné otevřené položky věnující se silným a slabým stránkám a návrhům na změny. $V$ tomto případě byl zvolen systém otevřeného kódování (Hendl, 2016; Švaříček \& Šed'ová, 2014), přičemž jednotlivé komentáře byly ručně označeny kódy, které byly následně sjednoceny do souvisejících oblastí. Přehled vybraných kódů, jejich stručnou charakteristiku a př́klad ilustrativního komentáře, který byl takovým kódem označen, je uveden $v$ tabulce 2 . Celkem bylo použito 30 různých kódů, z nichž 12 mělo pozitivní a 14 negativní charakter. Zbývající kódy nebylo možné zařadit ani do jedné ze zmíněných kategorií. Původní verze souboru kódů obsahovala kategorii „motivace“. Tento kód byl na doporučení recenzenta příspěvku odstraněn, protože nedostatečně rozlišoval rozdílné zdroje motivace 
v závislosti na různých teoretických konceptech. Komentáře zařazené do této kategorie byly přesunuty do kategorií vztahujících se k aktivizaci žáků (AKT) či k zábavnosti a zajímavosti daného zpracování (ZAJ).

\section{Tabulka 2}

Charakteristika vybraných kódů, u nichž byl zaznamenán komentář pozitivního i negativního charakteru, použitých při kódování otevřených položek, včetně vzorového př́kladu (autentický komentář z hodnoticích formulárự, psán kurzívou)

\begin{tabular}{|c|c|}
\hline Kód & Charakteristika a příklad \\
\hline AKT & $\begin{array}{l}\text { + aktivizace, snaha o probuzení zájmu o probíranou látku } \\
\text { Super motivace a aktivizace žáků. Všichni byli do aktivity zapojeni. } \\
\text { - } \quad \text { nedostatečně aktivizující, nudné, pro žáky př́liš pasivní aktivity } \\
\text { Chtělo by to žáky k aktivitě více motivovat. Chyběla mi tam větší aktivita. }\end{array}$ \\
\hline CAS & $\begin{array}{l}\text { + přesně časově rozvržené, přesný harmonogram } \\
\text { Skvěle, na minutu přesně, rozvržené. Jednotlivé aktivity na sebe plynule navazovaly. } \\
\text { - časová náročnost, zmatečné či zdlouhavé } \\
\text { V aktivitě byly zbytečné časové prostoje, kdy nebyla žádná činnost. Nestihlo se to. }\end{array}$ \\
\hline EMO & $\begin{array}{l}\text { + } \quad \text { komentář obsahující pozitivní emoce } \\
\text { Moc se mi tahle aktivita líbila. Tak bych chtěla někdy umět učit. } \\
\text { - } \quad \text { komentář obsahující negativní emoce } \\
\text { Nelíbilo se mi to. Takhle bych to sama nikdy nenavrhla. }\end{array}$ \\
\hline$J A Z$ & $\begin{array}{l}\text { + sympatický projev, spisovný jazyk, adekvátní tempo, pěkný zápis na tabuli } \\
\text { Máš pěkně hlasitý projev a pěkně jsi měnil intonaci. Oceňuji i pohyb po tř́dě. } \\
\text { - špatný projev (např. př́liš tichý, nespisovný či rychlý), malé písmo při zápisu } \\
\text { Občas mluvís moc rychle, což vede ke zmatenosti pokynü, a chce to přidat } \\
\text { na hlasitosti. }\end{array}$ \\
\hline KOM & $\begin{array}{l}\text { + vhodně prezentována celá aktivita, sděleny přesné pokyny a následně jejich } \\
\text { dodržení } \\
\text { Naprosto jasně vysvětleno, co budeme dělat. Přesná pravidla, která jsi dodržela. } \\
\text { - lépe komentovat podstatu činnosti, sdělit pokyny přesněji } \\
\text { Vůbec jsem nevěděla, co máme dělat. Na začátku jsi nevysvětlila, co je účelem } \\
\text { aktivity. }\end{array}$ \\
\hline NAZ & $\begin{array}{l}\text { + pěkně názorné, propojení s demonstrací pomůcek a dodržení všech zásad } \\
\text { Skvělé propojení s dostupnými pomúckami a jejich demonstrace žáküm. } \\
\text { - Špatná názornost, moc abstraktní, nevhodné pomůcky (napřs. příliš malé objekty) } \\
\text { Určitě by to chtělo doplnit nějakým modelem či přírodninou. Bylo to moc abstraktní. }\end{array}$ \\
\hline ODB & $\begin{array}{l}\text { + odborně správné, bez věcných chyb } \\
\text { Dokázal jsi, že máš problematiku výborně nastudovanou. Absolutně bez chyb. } \\
\text { - } \quad \text { nedostatečná odbornost, věcné chyby } \\
\text { V prezentaci byla spousta chyb, bylo by vhodné si vše dř́ve poř́ádně nastudovat. }\end{array}$ \\
\hline
\end{tabular}




\begin{tabular}{|c|c|}
\hline Kód & Charakteristika a příklad \\
\hline PEK & $\begin{array}{l}\text { + pěkně připravené, detailně nachystané a promyšlené } \\
\text { Skvělá př́prava, do detailu jsi to měla promyšlené, včetně záložního plánu. } \\
\text { - nepřipravené, potřeba vylepšit, nedomyšlené některé aktivity } \\
\text { Vůbec jsi neměl domyšlené, jak postupovat, když žáci odpovídají jinak. }\end{array}$ \\
\hline POP & $\begin{array}{l}\text { + popis aktivity bez hlubšího komentáře } \\
\text { Prezentace v PowerPointu a skupinová práce. } \\
\text { - } \quad \text { konstatování, že je aktivitu potřeba upravit (avšak bez rady, jak to provést) } \\
\text { Měl bys to změnit, tohle nefungovalo. }\end{array}$ \\
\hline VHO & $\begin{array}{l}\text { + vhodné, adekvátní věku žáků } \\
\text { Ideální aktivita pro žáky 7. tř́idy, dobře vyvážená odbornost a zábavnost. } \\
\text { nevhodné, neadekvátní věku žáků } \\
\text { Pro žáky základní školy je to moc těžké, rozhodně tam bylo moc oborných termínů. }\end{array}$ \\
\hline ZAJ & $\begin{array}{l}\text { + zajímavé, dobrý nápad, zábavné } \\
\text { Bylo to zábavné a moderně pojaté, žáky by taková aktivita určitě bavila. } \\
\text { - } \quad \text { Nezajímavé, nudné }\end{array}$ \\
\hline
\end{tabular}

\section{Výsledky}

Při vyhodnocení výsledků hodnoticích formulářů byly odděleně hodnoceny škálové položky a otevřené položky. U škálových položek bylo zjištováno průměrné bodové hodnocení (hodnotitelé vybírali na škále 1-10, více viz metodologie výzkumu) ve vztahu k vybraným pěti oblastem, dále byla hledána maxima a minima $\mathrm{v}$ průměrných hodnoceních a počítán medián (viz tabulka 3). Při analýze nebyl nalezen žádný formulář, v němž by některá položka nebyla vyplněna, což jen potvrzuje, že klasické hodnocení pomocí škály nedělá studentům výraznější problémy. Počet studentů hodnotících jednotlivé výstupy se pohyboval od 5 do 22 (s průměrem 12 a mediánem 11 hodnotitelů na výstup).

Z výsledků je patrné, že hodnocení byla převážně velmi pozitivní. Záměrně jsme v analýze hledali i minimální průměry, abychom zjistili, jaké nejnižší skóre se u jednotlivých oblastí objevilo. Pokud porovnáme hodnocení studentů učitelství př́rodopisu pro základní školy (označeno ZŠ) a učitelství biologie pro střední školy (označeno SŠ), tak není v hodnocení signifikantní rozdíl. Jediný významný rozdíl byl zjištěn u minimálního hodnocení v oblasti využitelnosti v praxi, v níž byli studenti učitelství pro základní školy značně kritičtější. 
Pokud srovnáváme hodnocení u jednotlivých oblastí, tak nejvyšší průměrné skóre bylo nalezeno u odborné správnosti daných výstupů. Naopak nejnižší průměrné skóre bylo zjištěno u atraktivity výstupu. Je však nutné podotknout, že rozdíl mezi nejvyšším a nejnižším průměrným hodnocením je pouze 0,8 bodu. Hodnocení studentů učitelství př́rodopisu a biologie se v tomto př́padě opět nelišila.

Tabulka 3

Vyhodnocení průměrného skóre u škálových položek hodnoticího formuláře.

\begin{tabular}{llccccccc}
\hline & & $\mathbf{1}$ & $\mathbf{2}$ & $\mathbf{3}$ & $\mathbf{4}$ & $\mathbf{5}$ & Celkem & Průměr \\
\hline Total & Průměr & 8,7 & 9,1 & 9,5 & 9,1 & 9,2 & 45,5 & 9,1 \\
& Max & 10,0 & 10,0 & 10,0 & 10,0 & 10,0 & 49,7 & 9,9 \\
& Min & 4,3 & 6,6 & 7,0 & 6,8 & 2,6 & 29,3 & 5,9 \\
& Medián & 9,0 & 9,4 & 9,7 & 9,3 & 9,5 & 46,5 & 9,3 \\
\hline Ž́ & Průměr & 8,7 & 9,2 & 9,5 & 9,1 & 9,3 & 45,8 & 9,2 \\
& Max & 10,0 & 10,0 & 10,0 & 10,0 & 10,0 & 49,7 & 9,9 \\
& Min & 4,3 & 6,6 & 7,0 & 6,8 & 2,6 & 29,3 & 5,9 \\
& Medián & 9,0 & 9,4 & 9,7 & 9,4 & 9,6 & 47,0 & 9,4 \\
\hline Š́ & Průměr & 8,5 & 9,0 & 9,4 & 9,0 & 9,1 & 44,9 & 9,0 \\
& Max & 9,8 & 9,5 & 9,9 & 9,8 & 10 & 48,7 & 9,7 \\
& Min & 5,9 & 7,6 & 8 & 7,6 & 7,7 & 41,1 & 8,2 \\
& Medián & 8,5 & 9,1 & 9,6 & 9,2 & 9,3 & 45,9 & 9,2 \\
\hline
\end{tabular}

Vysvětlivky: Total - celkové počty ( $\mathrm{N}=807) ;$ ZŠ - studenti učitelství př́rodopisu pro základní školy (N = 47); SŠ - studenti učitelství biologie pro střední školy (N = 19); 1 - Atraktivita; 2 - Zpracování; 3 - Správnost; 4 - Kvalita projevu; 5 - Využitelnost v praxi.

Vyhodnocení otevřených položek rozdělíme shodně jako v samotném formuláři do třech oblastí: silné a slabé stránky výstupu a navrhované změny.

V případě silných stránek se hodnotitelé nejčastěji věnovali dobré názornosti (celkem 166 komentářù), aktivizaci a snaze o probuzení zájmu žáků o probíranou látku (138 komentářu) a kvalitnímu jazykovému projevu (134 komentářo̊) daného studenta. Procentuální výskyt jednotlivých aspektů v komentářích je znázorněn v obrázku 1 . U 133 hodnoticích formulářủ nebyla uvedena žádná zpětná vazba (tyto formuláře byly vyřazeny $\mathrm{z}$ analýzy, tudíž procentuální počty v grafu vycházejí ze základu bez těchto nevyplněných formulářů). 


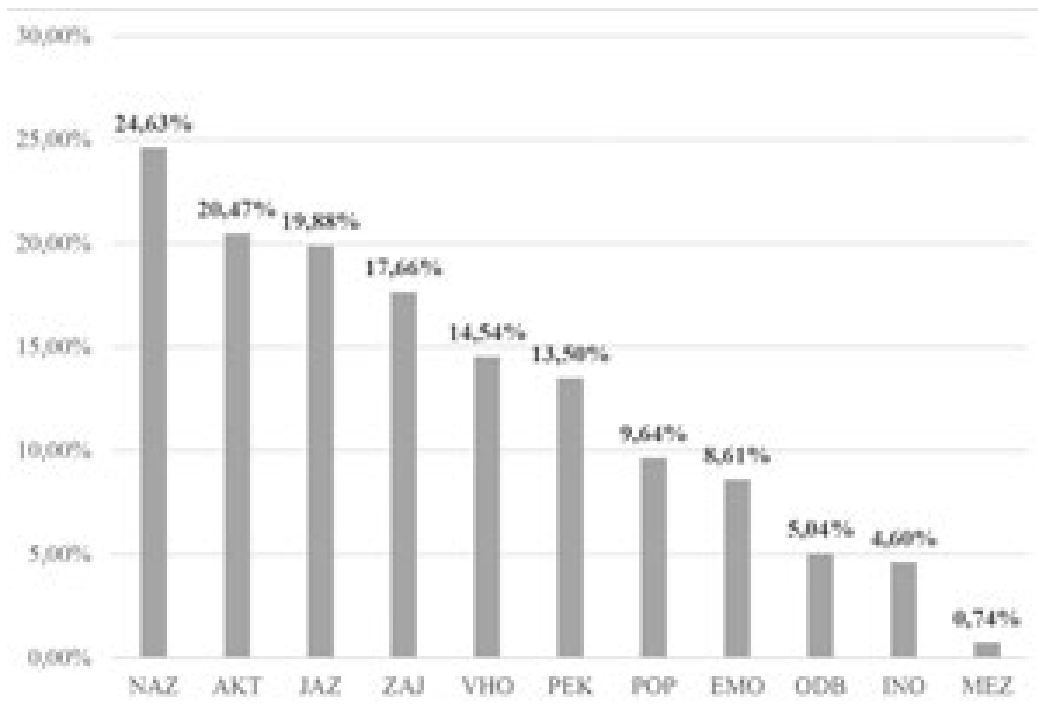

Obrázek 1. Silné stránky mikrovyučování - procentuální četnosti jednotlivých oblastí, na které se hodnotitelé ve své zpětné vazbě zaměřili $(\mathrm{N}=674)$. Vysvětlivky: NAZ - názornost; JAZ - jazykový projev; VHO - vhodnost, adekvátnost věku; PEK příprava, kvalita zpracování; AKT - aktivizace, snaha o probuzení zájmu o probíranou látku; POP - pouhý popis aktivity (bez hodnocení); EMO - emotivní komentář; ZAJ - zajímavost pro žáky; ODB - odbornost; INO - inovativní pojetí; MEZ - zahrnutí mezipředmětových vztahů

Pro názornost jsou níže uvedeny i příklady některých ilustrativních komentářů. Ve většině případů se hodnotitelé omezovali na stručná sdělení, ale $\mathrm{v}$ žádném z hodnoticích formulářủ nebyl zjištěn komentářr, který by měl nerelevantní obsah.

- Názornost: Hezký popis srdce a kde se který oddíl nachází, odkud kam teče krev. Vhodné přirovnání $k$ věcem z běžného života (např velikost srdce odpovídající zat'até pěsti).

- Aktivizace a snaha o probuzení zájmu žáků o probíranou látku: Pěkná aktivita a pro žáky motivující. Určitě by je to bavilo, velmi vhodně jsi použil situaci z běžného života, což je žákům blízké. 
- Jazykový projev: Moc pěkný projev, živý a bez balastních slov. Časté užívání otázek vytvořilo prríjemnou atmosféru a otázky byly vhodně pokládány tak, aby žáky vedly $k$ vyřešení úkolu.

- Odborná znalost: Prokázal si, že problematice opravdu rozumís. Líbilo se mi dávání faktů do souvislostí, ukazovalo to velmi dobrou orientaci v tématu.

Jak ukazuje poslední ilustrativní komentář, tak se hodnotitelé zaměřili také na odborné znalosti prezentujícího studenta. Celkem 34 komentářů obsahovalo zmínku o dobrých teoretických znalostech. $V$ pěti př́padech také hodnotitel vyzdvihl zahrnutí mezipředmětových vztahů, jednalo se však o jedno konkrétní mikrovyučování, v němž byla propojena výuka geologie a zeměpisu.

V případě slabých stránek mikrovyučování se hodnotitelé nejčastěji vyjadřovali $\mathrm{k}$ jazykovému projevu studenta (109 př́ípadů). Vytýkali zejména nedostatečnou hlasitost, používání balastních slov (např „vlastně“, „jakoby“) a občas i nespisovnou mluvu. Další častou výtkou byla vhodnost navržené aktivity pro žáky daného věku. Hodnotitelé zmiňovali, že aktivita není adekvátní věku žáků - konkrétně v 69 komentáŕích. Jestliže hodnotitel vytýkal nepřiměřenost dané aktivity, téměř vždy $\mathrm{v}$ navrhované změně uvedl, zda by aktivita měla být jednodušší či obtížnější. V 64 případech se hodnotícím studentům nelíbila příprava dané aktivity, přičemž většinou uváděli, že student vedoucí výuku neměl promyšlené všechny kroky či organizačně aktivitu nezvládal. Dále hodnotitelé vytýkali nízkou aktivizaci žáků (37 př́ípadů), časovou náročnost prezentované aktivity (29), její nevhodné uvedení bez vysvětlení podstaty (28) či odborné chyby (27). Třináct hodnotitelů vytklo prezentujícímu studentovi, že jeho výstup reprezentoval jinou vyučovací metodu, než jakou si původně vylosoval. Procentuální četnosti výskytu jednotlivých kódů v komentáŕích jsou shrnuty v obrázku 2. 


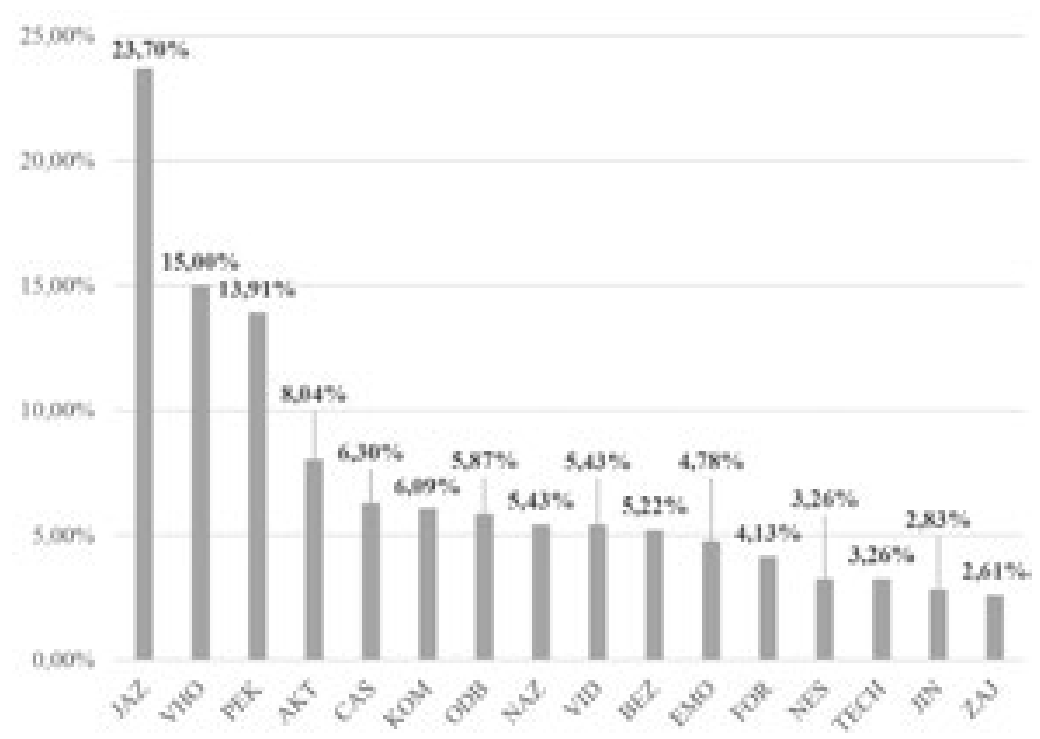

Obrázek 2. Slabé stránky mikrovyučování - procentuální četnosti jednotlivých oblastí, na které se hodnotitelé ve své zpětné vazbě zaměřili $(\mathrm{N}=460)$.

Vysvětlivky: JAZ - jazykový projev; VHO - nepřiměřená obtížnost vzhledem k věku žáků; PEK - nedostatečná příprava, kvalita zpracování; AKT - malá aktivizace žáků; CAS - časová náročnost; KOM - nedostatečný úvod a vysvětlení podstaty aktivity; ODB - malá odbornost, faktické chyby; NAZ - malá názornost; VID - špatně viditelné, zvolení nevhodných pomůcek; BEZ - bez připomínek (nebylo co vytýkat); EMO - negativní emotivní komentář; FOR formativní komentář upozorňující na chyby a navrhující, jak přesně nedostatky odstranit; NES nesouvisející komentář, subjektivní hodnocení; TECH - technické zpracování či problémy s ICT; JIN - jiná vyučovací metoda; ZAJ - nezajímavé, nudné

Shodně jako u pozitivních hodnocení i zde jsou uvedeny ilustrativní komentáře. V tomto případě se objevilo i několik nerelevantních komentářů (15 případů), které se nevztahovaly přímo k mikrovyučování či obsahovaly zcela subjektivní postoj hodnotitele vůči aktivitě.

- Jazykový projev: Občas Ti není rozumět, mluvíš moc rychle, a pak se často přeřekneš. Z toho občas plynou i faktické chyby, kterých se dopouštíš.

- Nepřiměřené věku žáků: Bylo tam moc otázek a málo času, pro 7. tř́du mi to přišlo moc náročné. Některé pojmy by sedmáci určitě neznali. 
- Nedostatečná příprava, kvalita zpracování: Brainstorming byl nedořešený, jak s tím, co žáci vymysleli, bude dál pracováno? Pokud by to bylo dopredu připravené a zapojili by se někteři žáci, tak by to asi fungovalo, takto ostatní jen koukali a nic nedělali.

- Časová náročnost: Aktivita zabere hodně času, v běžné třídě bys neměla šanci toto stihnout.

- Nedostatečný úvod a vysvětlení podstaty aktivity: Bylo to nejasné, zabralo spoustu času pochopit, co se vlastně po nás chce. To jsi měla vysvětlit na začátku a aktivita by byla hned prehlednější.

- Jiná vyučovací metoda: Nejsem si jistý, jestli to byla teda diskuze. Spíše mi to príšlo jako inscenační metoda.

- Nerelevantní komentář: Líbí se mi, že sis na výuku oběhové soustavy vzala mikinu se srdcem.

Třetí položka se vztahovala k navrhovaným změnám. $\mathrm{V}$ tomto př́padě nás nejvíce zajímalo, zda jsou hodnotitelé schopni svým kolegům poradit, jak svůj výstup vylepšit. Hledali jsme tedy taková hodnocení, která by měla formativní charakter. To znamená, že obsahovala konkrétní radu, jak dosáhnout lépe vytyčeného cíle. Takových komentářủ bylo nalezeno 37, což představuje necelou desetinu všech formulářủ. Samozřejmě, že se hodnotitelé snažili často nasměrovat své kolegy k zlepšení jejich výkonu, ale prostřednictvím prostého konstatování, že mají něco změnit, kdy svůj komentář nevztahovali ke konkrétním cílům či kompetencím (pozn. takové komentáře jsme neoznačili jako „formativní"). Např́iklad ve 49 komentářích byla pouze zmínka, že by bylo vhodné aktivitu upravit, ale zpětná vazba již neobsahovala informaci, jakým způsobem by tato modifikace měla být provedena.

Nejčastěji se hodnotitelé vyjadřovali k vhodnosti dané aktivity pro žáky daného věku (102 komentářů). Někteří navrhovali zjednodušení dané aktivity (45), jiní naopak připojili nápady na její rozš́řrení (57). Dále radili vylepšit jazykový projev (60) ve smyslu odstranění balastních slov, změny intonace či zvýšení hlasitosti. Často také navrhovali pečlivější př́ípravu (64) ve vztahu k práci s danými materiály či předvídání jiných odpovědí žáků. S tím souviselo i zvýšení názornosti (37), kdy doporučovali různé pomůcky či přírodniny, které ke své aktivitě mohl prezentující student využít. Další četnosti kódů jsou shrnuty v obrázku 3 . V tomto př́padě je nutné dodat, že 380 formulářu nemělo tuto položku vyplněnou, což by mohlo být chápáno tak, že hodnotitel 
byl s aktivitou spokojen a neměl žádný návrh na její úpravu. Avšak dovolím si zde ztotožnit se s komentářem jednoho $\mathrm{z}$ recenzentů první verze příspěvku, který velmi vhodně podotkl, že v souvislosti s poskytnutím relevantní zpětné vazby by student učitelství měl být schopen ocenit také to, co bylo zvládnuto a co se podařilo (viz Lu \& Bol, 2007). Pozitivní zpětná vazba je bezpochyby velmi důležitá, avšak obecně se v našem vzdělávacím prostředí setkáme spíše s hledáním chyb než oceněním dílčích úspěchů žáka.

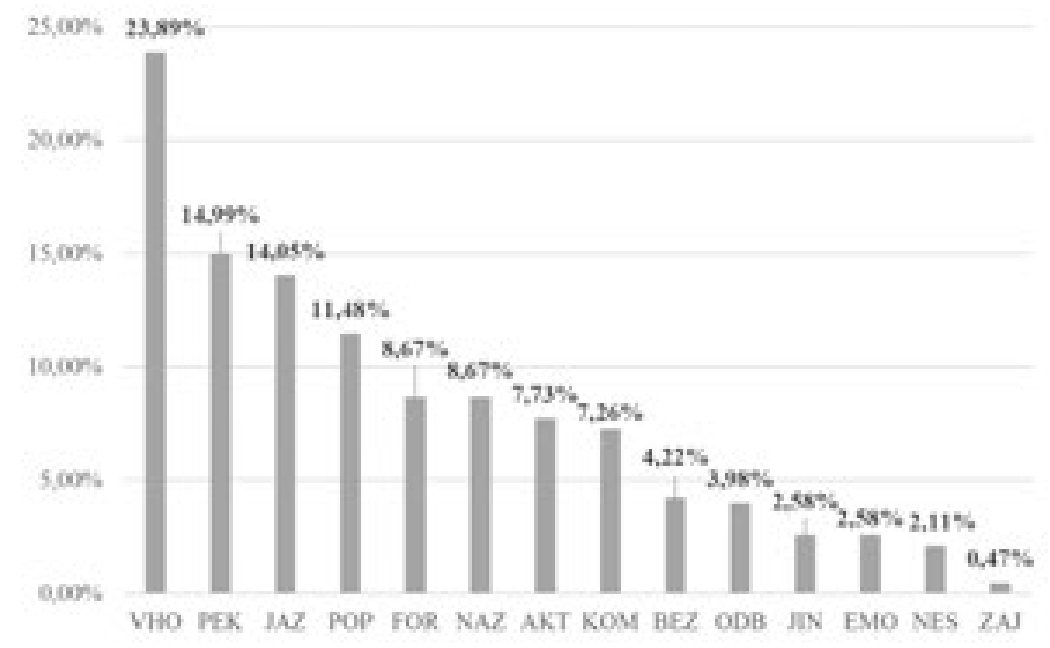

Obrázek 3. Navrhované změny - procentuální četnosti jednotlivých oblastí, na které se hodnotitelé ve své zpětné vazbě zaměřili $(\mathrm{N}=427)$.

Vysvětlivky: VHO - úprava vzhledem k přiměřenosti věku žáků (zjednodušení či přidání aktivit); JAZ - jazykový projev; PEK - změny v přípravě a kvalitě zpracování; POP - pouhé konstatování, že aktivita by měla být změněna, ale bez jakékoliv rady, jak to zrealizovat; FOR - formativní komentář navrhující, jak odstranit nedostatky a lépe dosáhnout vytyčeného cíle; NAZ - zvýšení názornosti, přidání pomůcek; AKT - návrh na zvýšení zapojení žáků, aktivizace; KOM - lépe uvést aktivitu a vysvětlit její podstatu; BEZ - bez připomínek; ODB - zlepšení odbornosti aktivity, odstranění faktických chyb; JIN - návrh na přepracování, aby se jednalo o jinou vyučovací metodu; EMO - emotivní komentář (pouze konstatování, že aktivita se hodnotiteli líbila/nelíbila); NES - nesouvisející komentář, subjektivní hodnocení; ZAJ - zvýšit zajímavost tématu pro žáky 
Na následujících řádcích jsou opět prezentovány ilustrativní komentáře ve vztahu k navrhovaným změnám.

- Úprava vzhledem $\mathrm{k}$ přiměřenosti věku žáků: Text bys měla připravit jen bodově, tento byl pro žáky 8. třídy moc obsáhlý.

- Jazykový projev: Snaž se mluvit pomaleji a při psaní na tabuli si stoupni príště víc stranou, at' je vidět, co píšeš.

- Změny v př́ípravě a kvalitě zpracování: Celé třídě dát úvod a všechny seznámit s detaily aktivity, aby věděli, co se po nich chce.; Přiště si lépe promysli, co chceš, v kterém momentu říkat, aby to mělo logickou posloupnost.

- Pouhé konstatování nutnosti změny: Kdyby se eliminovaly chyby, tak by to bylo super.; Měl bys to upravit.

- Formativní komentář: Vzhledem $k$ tomu, že pavouk byl malý, tak bych př́ístě vzala ještě i obrázek nebo plakát, kterým bych výklad doplnila. Lépe bys tak zajistila názornost a žáci by mohli porovnat stavbu na obrázku a na živém pavoukovi.

- Zajímavost pro žáky: Vím, že u obyčejného výkladu je motivace náročnější, ale něco tam zaznít mohlo. Určitě by tam šla přidat nějaká zajímavá informace, která by žáky zaujala. Pro mě to bylo trochu nuda.

\subsection{Odpovědi na výzkumné otázky}

První výzkumná otázka se zaměřovala na schopnost studentů učitelství poskytnout zpětnou vazbu na výkon svých vrstevníků. Bylo zjištěno, že studenti učitelství zpětnou vazbu poskytnout dokáží, ale je vhodné je k tomu vybavit hodnoticím nástrojem. Ideální je nástroj s určitou strukturou, který je nasměruje na klíčové aspekty mikrovyučování, jichž si ve vztahu k pedagogickým kompetencím svých spolužáků mají všímat. Pozitivním zjištěním je, že se ve zpětné vazbě velmi omezeně vyskytovaly komentáře $s$ emotivní složkou (pokud ano, tak se jednalo o pozitivní komentáře, kde hodnotitel uváděl, že se mu daná aktivita velmi líbí). Nesetkali jsme se s negativními komentáři založenými na osobních postojích či vztazích s hodnoceným studentem. Hodnotitelé se opravdu snažili zaměřit na obsah výstupu a jeho zvládnutí.

Druhá výzkumná otázka sledovala, zda studenti učitelství ochotněji hodnotí pomocí škálové stupnice, nebo raději poskytnou vrstevníkovi slovní komentář. $V$ tomto případě není překvapivým zjištěním, že škálové položky vyplnili 
všichni hodnotitelé (ani u jednoho formuláře nebyla zjištěna nevyplněná položka). Zatímco u slovních komentářu často zpětná vazba chyběla. Zde je nutné dodat, že nižší počet odpovědí vztahujících se k návrhům na změny či zmínění slabých stránek mohl být ovlivněn i tím, že mikrovyučování bylo kvalitně připraveno, tudíž nebylo potřeba navrhovat změny či popisovat slabá místa výstupu.

Třetí výzkumná otázka se přímo vztahovala k formativnímu hodnocení, jelikož byla zaměřena na množství komentářů ve zpětné vazbě, které měly formativní charakter. Tím je myšleno, že obsahovaly informaci o tom, co je potřeba v mikrovyučování vylepšit, aby bylo př́ŕště efektivnější a snadněji došlo k naplnění vytyčených cílů. Takové komentáře jsme našli ve 37 případech u položky věnující se návrhům na změny a v 19 případech u popisu slabých stránek výstupu. Právě u slabých stránek byl formativní komentář velmi cenný, jelikož ihned obsahoval radu, jak se př́ště stejné chybě vyhnout. Hodnotitelé často uváděli spoustu doporučení, která však nevztahovali ke konkrétnímu cíli či kompetenci, popřípadě se jednalo jen o velmi obecná doporučení. Formativní zpětná vazba by se možná v komentářích objevila častěji, pokud by hodnotitelé měli na vyplnění formulářů více času a mohli se více rozepsat.

Poslední výzkumná otázka zjištovala aspekty, na které se ve svém hodnocení hodnotitelé zaměřili. Zároveň nás zajímalo, zda zpětná vazba obsahuje emotivní komentáře. Nejčastěji se hodnotitelé zaměřovali na jazykový projev studenta, a to celkem v 303 komentárích (z toho 134 u silných stránek, 109 u slabých stránek a 60 u návrhů na změnu). Druhým nejčastějším aspektem byla adekvátnost zpracování ve vztahu ke znalostem a dovednostem žáků a jejich věku (269 případů) a následně názornost daného výstupu (228 př́padů). Emoce se do hodnocení promítaly poměrně málo, nejčastěji u hodnocení silných stránek mikrovyučování (58 př́ípadů), kdy hodnotitel psal, že se mu aktivita líbila a rád by ji také vyzkoušel. Při hodnocení slabých stránek se většinou negativní komentáře objevovaly ve vztahu k dané vyučovací metodě, která se hodnotiteli nelíbila (popř. se mu nelíbilo její uchopení ze strany studenta vedoucího výuku). Nesouvisející komentář se objevil v 15 prŕpadech u hodnocení slabých stránek výstupu a v 9 případech u návrhů na změny. Je nutné dodat, že se většinou jednalo o subjektivní komentár̆, který nebyl útočný, spíše naopak se snažil situaci odlehčit vtipem či vlastním pohledem na problematiku. 


\section{Diskuze}

Mikrovyučování je bezpochyby cennou součástí pregraduální přípravy studentů učitelství, jelikož si studenti vyzkouší reálnou výukovou situaci (Fernández, 2005, 2010). Zároveň se lépe učí plánovat užití i praktickou realizaci různých vyučovacích forem a metod, protože je možné snadno kontrolovat různé aspekty vyučovacího procesu (Amobi, 2005; Fernández \& Robinson, 2006; Kpanja, 2001). Mikrovyučování má pozitivní vliv i na rozvoj komunikačních dovedností studentů učitelství (Benton-Kupper, 2001; Fernandéz, 2005; Sedláček, 2016), jelikož mají možnost vést výuku, zapojovat se do dialogů a diskuzí, sdílet a obhajovat vlastní nápady a kriticky posuzovat nápady svých kolegů (Pringle, Dawson, \& Adams 2003). Možnost vyzkoušet si výukové aktivity $\mathrm{v}$ simulovaných podmínkách pomáhá studentům osvojit si a upevnit klíčové pedagogické kompetence, ale také uvědomit si úskalí některých aktivit, pokud si je zkouší z pozice žáka či pozorovatele (Horká, 1997; I'anson, Rodriques, \& Wilson, 2003).

Vítečková (2019) zjištovala potřeby 217 začínajících učitelů. Nejčastěji dotazovaní učitelé uvedli, že by potřebovali prakticky rozvíjet svoje metodické a didaktické dovednosti, účastnit se dalšího vzdělávání v oblasti speciální pedagogiky a zlepšit své schopnosti v řešení obtížných či zátěžových situací. V př́ípadě, že jsou začínající učitelé dotazováni na svou pregraduální př́ípravu, tak často vytýkají fakultám připravujícím budoucí učitele nedostatečný prostor pro vyzkoušení různých situací ve výuce a pro nácvik pedagogických dovedností (Vítečková, 2019). Autorka ale dodává, že si nemyslí, že by zvýšení kvality vysokoškolské př́ípravy spočívalo pouze ve zvýšení hodinové dotace praxe a propojení teorie s praxí, ale důraz by měl být kladen na kvalitnější reflexi a aplikaci teoretických poznatků pro pochopení či řešení skutečných pedagogických situací. Jak uvádí Vítečková (2019) či Nezvalová (2002), není možné zlepšovat pregraduální př́pravu budoucích učitelů, pokud se nebudeme soustředit na porozumění jejich názorům na výuku, subjektivním teoriím a vlastnímu pohledu na proces vyučování. $V$ tomto ohledu je velmi důležitá i reflexe a sebereflexe, protože pomáhá porozumět tomu, jak daný jedinec přemýšlí nad svým jednáním a chováním či jednáním a chováním svých kolegů. To podporuje i Horká (1997), která doporučuje se studenty více rozbírat jejich mikrovýstupy $\mathrm{v}$ rámci oborových didaktik a akcentovat jejich sebereflexi. Význam reflexe $\mathrm{v}$ přípravě učitelů či $\mathrm{v}$ rámci jejich dalšího vzdělávání je zdůrazňován i ve vztahu k profesnímu vidění, tzn. schopnosti všímat si, kterou lze považovat za indikátor učitelských kompetencí (Janík et al., 
2014; Minaříková et al., 2016). Empirické studie dokazují, že studenti učitelství si při analýze videozáznamů výuky všímají zejména činností učitele (Sonmez \& Hakverdi-Can, 2012), organizace výuky, ale již méně samotných žáků a jejich reakcí (Star \& Strickland, 2008). Pokud by byly mikrovýstupy nahrávány na video a s odstupem času opět analyzovány, tak by se studenti při správném vedení mohli naučit všímat i dříve přehlížených detailů. Hodnotitelé by tak poskytovali komplexnější reflexi a student vedoucí výuku by se lépe naučil reflektovat vlastní práci a vnímat osobní účinnost jako učitele (z angl. self-efficacy) (Arsal, 2014; Donelly \& Fitzmaurice, 2011; Mergler \& Tangen, 2010).

Zpětná vazba, kterou student obdrží po svém výkonu, je velmi ceněnou reflexí, jelikož při průběžné či souvislé praxi může být kvalita zpětné vazby často ovlivněna nedostatkem času. Ukázalo se, že studenti učitelství jsou schopni hodnotit výkon svých kolegů, ale je vhodné, pokud mají k dispozici hodnoticí nástroj. Díky takovému nástroji mohou lépe zaměřit svou pozornost na klíčové aspekty mikrovyučování. Hodnotitelé preferovali škálové položky, což je opět v souladu s již publikovanými výzkumy (např. Panadero, Romero, \& Strijbos, 2013) a toto zjištění není překvapivé, protože obecně je poskytnutí slovní zpětné vazby náročnější. Nicméně, jak uvádí odborná literatura (Dijks, Brummer, \& Kostons, 2018; Liu et al., 2001; Lu \& Bol, 2007), taková zpětná vazba je pro hodnoceného studenta či žáka podstatně př́nosnější.

Pokud se podíváme na to, jaké aspekty nejvíce ve zpětné vazbě hodnotitelé sledovali, at’ při konstatování silných, tak slabých stránek mikrovyučování, zjistíme, že se nejvíce zaměřovali na jazykový projev studenta, způsob aktivizace a motivace žáka. K podobným zjištěním dospěla ve svém výzkumu Horká (1997), která u studentů učitelství 1. stupně zjistila, že nejčastěji hodnotili kriticky své komunikativní dovednosti. Pozitivně dotazovaní studenti hodnotili schopnost aktivizovat žáky a pomocí různých aktivit probudit jejich zájem o danou problematiku (Horká, 1997).

S našimi výsledky se shodují i závěry studií Šmahelové (2005) a Fabiánkové (2002), které sledovaly, jak hodnotí studenti učitelství 1. stupně své dovednosti po absolvování výstupu v rámci didaktiky prvouky. Studenti učitelství v těchto studiích uvedli, že je pro ně obtížná volba metod a forem práce, zejména zařazování aktivizačních metod. Někteří také uváděli problém s výběrem přiměřeného množství učiva, které chtějí žákům předávat, a problémy s vyjadřováním (Šmahelová, 2005). To byl také jeden z aspektů, který 
se objevoval $\mathrm{v}$ hodnocení studentů zapojených do našeho výzkumu, kteří zmiňovali přiměřenost dané aktivity ve vztahu $\mathrm{k}$ věku daných žáků a často navrhovali zjednodušení aktivity či naopak její rozšíření. Další dva zajímavé pohledy přináší studie zaměřené na profesní vidění studentů učitelství matematiky. Stehlíková (2010) zjistila, že studenti učitelství matematiky i učitelé z praxe při komentování videozáznamu výuky akcentovali aktivitu žáků, ale již méně didaktické aspekty sledovaných situací. Se studenty učitelství matematiky pracovaly i Vondrová a Žalská (2012), které prokázaly, že se studenti zaměřovali spíše na obecné aspekty výuky než na matematické jevy. Je zjevné, že hodnocení těchto oblastí je pro studenty učitelství snadnější, avšak pro jejich profesi je nutné se naučit všímat si i didaktických aspektů činnosti učitele a celkově zlepšit vnímání své osobní účinnosti (self-efficacy).

Za pozitivní zjištění můžeme považovat fakt, že se do zpětné vazby nijak nepromítaly osobní vztahy mezi studenty, což je často diskutovaný limit pro vrstevnické hodnocení (Lu \& Bol, 2007). V našem případě jsme záměrně používali anonymní hodnoticí formuláře, které proces poskytování upřímné zpětné vazby mohou podpořit, což opět potvrzuje i odborná literatura (např. Lu \& Bol, 2007; Vickerman, 2009; van Gennip, Segers, \& Tillema, 2010). Anonymní dotazníky byly zvoleny i z toho důvodu, že někteří studenti se mohou cítit při hodnocení před celou skupinou nepř́ijemně (Lefstein \& Snell, 2011) či se bojí kriticky vyjádřit k práci kolegy (Zhang, Lundeberg, \& Koehler, 2015). Zároveň měl tento způsob pomoci zabránit reflektování osobních vztahů mezi studenty do zpětné vazby a také snížit vliv tzv. př́lišné politické korektnosti, při níž učitelé ve snaze být korektní nekomentují výuku detailně (Lefstein \& Snell, 2011; Minař́íková et al., 2016).

Lze říci, že studenti učitelství neměli s poskytováním zpětné vazby výraznější problémy. Mohlo to být způsobeno tím, že již absolvovali některé předměty pregraduální př́pravy, v nichž byli s tímto přístupem seznámeni. $\mathrm{V}$ rámci předmětu didaktiky prŕrodopisu, respektive didaktiky biologie, si vyzkoušeli i poskytování zpětné vazby „nanečisto“. Většina studií, které byly v českých podmínkách realizovány, se zaměřovala na vrstevnické hodnocení mezi žáky na základních a středních školách. Př́kladem může být studie Rokose a Liškové (2019), kteří porovnávali hodnocení žáků základní školy, žáků nižšího stupně víceletého gymnázia, učitele a výzkumníka a posuzovali obsahovou stránku poskytnuté zpětné vazby. Ukázalo se, že malá zkušenost žáků má vliv na kvalitu poskytované zpětné vazby, zejména na její obsahovou stránku, kdy si žáci nejsou často jisti správným řešením. Žáci na základní škole a gymnáziu měli také problém s užitím popisného jazyka, takže autoři 
doporučují nechat žáky formulovat zpětnou vazbu ve skupinách, popřípadě provádět vrstevnické hodnocení formou diskuze, čímž může dojít k vyjasnění správného řešení a zároveň se žáci učí pracovat se svou vlastní chybou (Rokos \& Lišková, 2019).

Komentáře, které by měly formativní charakter, se nevyskytovaly ve zpětné vazbě př́liš často, ale $\mathrm{v}$ případě, že hodnotitel poskytl formativní zpětnou vazbu, tak byla správná a poskytovala hodnocenému studentovi důležitou informaci. Jak již bylo uvedeno u výsledků, formativní komentáře byly nalezeny v devatenácti případech u vytýkání slabých stránek, kdy hodnotitel připojil hned nápad na vylepšení a opravu, a v 37 př́padech u návrhů změny v mikrovyučování. Pro příští realizaci výzkumu bude potřeba hodnotitelům poskytnout více prostoru a času na psaní komentářů, jelikož kvalitní formativní komentáře nelze psát zcela stručně a v rychlosti. S tím souvisí i již zmíněný fakt, že se hodnotitelé často při hodnocení pedagogických dovedností zaměřovali na ty jednodušší (napřr kvalitu projevu či organizaci výuky), což koresponduje s výzkumem Horké (1997), v němž se hodnotitelé také zaměřili na posouzení organizace výuky, jak udržet žáky v klidu a na jejich motivaci. Z negativních postřehů se studenti ve studii Horké (1997) zaměřili na spisovnost vyjadřování, formulaci otázek, gestikulaci a opakování balastních slov. Daná sada kritérií, která byla použita pro vyhodnocení zpětných vazeb, se zdá být adekvátní (po úpravě spočívající se zrušením kódu věnujícímu se motivaci), jelikož kategorie odpovídaly i podobně orientovaným výzkumům. Ačkoliv desetistupňová škála umožňovala jemnější hodnocení (záměrně nebyla použita pětistupňová škála, která by mohla evokovat klasickou klasifikaci), tak by $\mathrm{v}$ tomto př́padě mohl být hodnoticí formulář modifikován $\mathrm{v}$ tom smyslu, že by škálu nahradily emotikony, př́ípadně tzv. teploměry, na kterých se hodnocení znázorňuje graficky. Tato forma je obecně označována za užitečnou v procesu vrstevnického hodnocení u žáků základní či střední školy, avšak domnívám se, že by byla aplikovatelná i do zde popisovaného vrstevnického hodnocení mezi studenty učitelství.

Závěrem bych rád dodal, že získaná data nelze zcela generalizovat, nicméně existuje podobnost s výsledky již realizovaných studií. Vrstevnické hodnocení začleněné do mikrovyučování v rámci pregraduální přípravy studentů učitelství je významným prvkem, který může př́ípravu učitelů zkvalitnit (Arsal, 2014). Získávají nejen více pohledů na svůj výstup, ale zároveň se učí zásadám formativního hodnocení z pozice hodnotitele i hodnoceného. Naším cílem je v této studii pokračovat a dále sledovat, zda se postupně schopnost poskytovat adekvátní zpětnou vazbu bude u studentů učitelství zlepšovat, 
zejména kvůli novým akreditacím učitelských oborů. Zároveň bychom chtěli proces poskytování zpětné vazby digitalizovat, jelikož v současné době je práce s papírovými formuláři značně náročná. A hodnotitelé by tak měli v jejím poskytování větší volnost a mohli by se více rozepsat, což by podporovalo častější užití formativní zpětné vazby. Další zamýšlenou modifikací je nahrávání mikrovyučování na kameru, aby výstup studenta bylo možné analyzovat s odstupem času. Tento postup by umožnil i srovnání hodnocení studentů $\mathrm{s}$ expertním hodnocením didaktika, které nebylo $\mathrm{v}$ této studii provedeno, protože pro relevantnost dat by bylo vhodné, aby hodnotitelem byla osoba bez osobního zájmu na výsledcích studie (pořízení videozáznamu umožní oslovit externí hodnotitele, kteří nejsou vyučujícími daného předmětu). Zároveň zde spatřujeme potenciál pro rozvíjení profesního vidění studentů učitelství, kteří by se pomocí analýzy videozáznamů mohli naučit lépe reflektovat učitelskou profesi a všímat si jejích klíčových aspektů.

\section{Závěr}

Studie sledovala, zda vrstevnické hodnocení představuje vhodné doplnění mikrovyučování používaného $\mathrm{v}$ pregraduální př́ípravě studentů učitelství. Ukázalo se, že studenti učitelství nemají problém s hodnocením svých spolužáků v případě, že hodnotí prostřednictvím škálových položek. Písemnou zpětnou vazbu však poskytují již méně ochotně. Zároveň je vhodné poskytnout hodnotitelům strukturovaný hodnoticí nástroj, který jim pomůže zaměřit se na klíčové aspekty ve výkonu jejich vrstevníka. Z oblastí, na které se studenti zaměřili nejvíce, dominoval jazykový projev, adekvátnost navržené aktivity $\mathrm{k}$ věku žáků a způsob motivace a aktivizace žáků. V minimálním počtu př́ípadů byly nalezeny komentáře, $v$ nichž by hodnotitel reflektoval vlastní emoce či vztah k hodnocenému žákovi. Pokud se emotivní zpětná vazba objevila, měla převážně pozitivní a motivující charakter. Komentáře s formativními rysy se vyskytovaly s menší četností, ale v případě, kdy se hodnotitel snažil poskytnout vrstevníkovi radu, jakým způsobem svůj výkon zlepšit tak, aby lépe dosáhl vytyčeného cíle, byly tyto komentáře adekvátní a přinesly hodnocenému studentovi užitečné informace.

Z našeho pohledu je užití vrstevnického hodnocení v pregraduální př́ípravě žádoucím prvkem, jelikož pomáhá pochopit studentům učitelství kladné i záporné stránky tohoto př́stupu, zejména tím způsobem, že si jej aktivně vyzkouší v roli hodnotitele i hodnoceného. 


\section{Literatura}

Allen, D. W., \& Ryan, K. (1969). Microteaching. Boston: Addison-Wesley Publishing.

Amobi, F. A. (2005). Pre-service teachers' reflectivity on the sequence and consequences of teaching action in a microteaching experience. Teacher Education Quarterly, 32(1), 115-130.

Andon, N. J., Dewey, M., \& Leung, C. (2017). Tasks in the pedagogic space: Using online discussion forum tasks and formative feedback to develop academic discourse skills at Master's level. In V. Samuda, K. V. van Branden, \& M. Bygate (Eds.), TBLT as a researched pedagogy (s. 236-263). Amsterdam: John Benjamins Publishing Company.

Arsal, Z. (2014). Microteaching and pre-service teachers' sense of self-efficacy in teaching. European Journal of Teacher Education, 37(4), 453-464.

Bakir, S. (2014). The effect of microteaching on the teaching skills of preservice science teachers. Journal of Baltic Science Education, 13(6), 789-801.

Benton-Kupper, J. (2001). The microteaching experience: Student perspectives. Education, 121(4), 830-835.

Berry, R. (2008). Assessment for learning. Hong Kong: Hong Kong University Press.

Boud, D., \& Molloy, E. (2013). Rethinking models of feedback for learning: The challenge of design. Assessment \& Evaluation in Higher Education, 38(6), 698-712.

Cantillon, P., \& Sargeant, J. (2008). Giving feedback in clinical settings. British Medical Journal, 337(1961), 1292-1279.

Dijks, M. A., Brummer, L., \& Kostons, D. (2018). The anonymous reviewer: The relationship between perceived expertise and the perceptions of peer feedback in higher education. Assessment \& Evaluation in Higher Education, 43(8), 1258-1271.

Donnelly, R., \& Fitzmaurice, M. (2011). Towards productive reflective practice in microteaching. Innovations in Education and Training International, 48(3), 335-346.

Ducasse, A. M., \& Hill, K. (2019). Developing student feedback literacy using educational technology and the reflective feedback conversation. Practitioner Research in Higher Education, 12(1), 24-37.

Evans, C. (2013). Making sense of assessment feedback in higher education. Review of Educational Research, 83(1), 70-120.

Fabiánková, B. (2002). Rozvíjení sebereflektivních dovedností studentů v didaktice prvouky a profesionálním praktiku. In V. Švec (Ed.), Cesty $k$ učitelské profesi: utvárení a rozvíjení pedagogických dovedností (s. 168-184). Brno: Paido.

Fernández, M. L. (2005). Learning through microteaching lesson study in teacher preparation. Action in Teacher Education, 26(4), 37-47.

Fernández, M. L. (2010). Investigating how and what prospective teachers learn through microteaching lesson study. Teaching and Teacher Education, 26(2), 351-362.

Fernández, M. L., \& Robinson, M. (2006). Prospective teachers' perspectives on microteaching lesson study. Education, 127(2), 203-215.

Geithner, C. A., \& Pollastro, A. N. (2016). Doing peer review and receiving feedback: Impact on scientific literacy and writing skills. Advances in Physiology Education, 40(1), 38-46.

Gibbs, G. (2010). Using assessment to support student learning. Leeds: Leeds Metropolitan University.

Gibbs, G., \& Simpson, C. (2004). Conditions under which assessment supports student learning. Learning \& Teaching in Higher Education, 1(1), 1-31. 
Hattie, J., \& Timperley, H. (2007). The power of feedback. Review of Educational Research, 77(1), 81-112.

Henderson, M., Boud, D., Molloy, E., Dawson, P., Phillips, M., Ryan, T., \& Mahoney, P. (2018). Feedback for learning. Closing the assessment loop. Framework for effective learning. Canberra, Australia: Australian Government, Department for Education and Training.

Hendl, J. (2016). Kvalitativní výzkum: základní metody a aplikace. Praha: Portál.

Horká, H. (1997). Mikrovýstupy jako prostředek seberozvíjení studentů v profesionálním praktiku. Pedagogická orientace, 7(4), 29-34.

Cho, K., \& MacArthur, C. (2011). Learning by reviewing. Journal of Educational Psychology, 103(1), 73-84.

I'Anson, J., Rodrigues, S., \& Wilson, G. (2003). Mirrors, reflections and refractions: The contribution of microteaching to reflective practice. European Journal of Teacher Education, 26(2), 189-199.

Janík, T., Minaříková, E., Píšová, M., Kostková, K., Janík, M., \& Hublová, G. (2014). Profesní vidění u učitelů: pokus o zmapování výzkumného pole. Pedagogika, 64(2), 151-176.

Jonsson, A. (2013). Facilitating productive use of feedback in higher education. Active Learning in Higher Education, 14(1), 63-76.

Knight, P. T., \& Yorke, M. (2003). Assessment, learning and employability. Maidenhead: SRHE and Open University Press.

Koenig, J. A. (Ed.). (2011). Assessing 21st century skills. Washington: The National Academies Press.

Kpanja, E. (2001). A study of the effects of video tape recording in microteaching training. British Journal of Educational Technology, 32(4), 483-486.

Le Hebel, F., Constantinou, C. P., Hospesova, A., Grob, R., Holmeier, M., Montpied, P., Moulin, M., Petr, J., Rokos, L., Stuchlikova, I., Tiberghien, A., Tsivitanidou, O., \& Zlabkova, I. (2018). Students' perspectives on peer assessment. In J. Dolin \& R. Evans (Eds), Transforming assessment (s. 141-174). Springer International Publishing.

Lefstein, A., \& Snell, J. (2011). Professional vision and the politics of teacher learning. Teaching and Teacher Education, 27(3), 505-514.

Liu, E. Z., Lin, S. S., Chiu, C. H., \& S. M. Yuan, S. M. (2001). Web-based peer review: The learner as both adapter and reviewer. IEEE Transactions on Education, 44(3), 246-251.

Lu, R., \& Bol, L. (2007). A comparison of anonymous versus identifiable e-peer review on college student writing performance and the extent of critical feedback. Journal of Interactive Online Learning, 6(2), 100-115.

Mathan, S. A., \& Koedinger, K. R. (2005). Fostering the intelligent novice: Learning from errors with metacognitive tutoring. Educational Psychologist, 40(4), 257-265.

Mergler, A. G., \& Tangen, D. J. (2010). Using microteaching to enhance teacher efficacy in preservice teachers. Teaching Education, 21(2), 199-210.

Metcalfe, J., \& Kornell, N. (2007). Principles of cognitive science in education: The effects of generation, errors, and feedback. Psychonomic Bulletin \& Review, 14(2), 225-229.

Meusen-Beekman, K. D., Joosten-ten Brinke, D., \& Boshuizen, H. P. A. (2015). Developing young adolescents' self-regulation by means of formative assessment: A theoretical perspective. Cogent Education, 2(1), 1-16.

Miao, Y., Badger, R., \& Zhen, Y. (2006). A comparative study of peer and teacher feedback in a Chinese EFL writing class. Journal of Second Language Writing, 15(3), 179-200. 
Minaříková, E., Uličná, K., Píšová, M., Janík, T., \& Janík, M. (2016). Videokluby jako forma profesního vzdělávání učitelů: otevřenost komunikace z pohledu učitelů. Pedagogika, 66(4), 443-461.

Nicol, D., Thomson, A., \& Breslin, C. (2014). Rethinking feedback practices in higher education: A peer review perspective. Assessment \& Evaluation in Higher Education, 39(1), 102-122.

Panadero, E., Romero, M., \& Strijbos, J. W. (2013). The impact of a rubric and friendship on peer assessment: Effects on construct validity, performance, and perceptions of fairness and comfort. Studies in Education Evaluation, 39(4), 195-203.

Pasch, M., Gardner, T. G., Langerová, G. M., Starková, A. J., \& Moodyová, Ch. D. (2005). Od vzdělávacího programu $k$ vyučovací hodině. Praha: Portál.

Poulos, A., \& Mahony, M. (2008). Effectiveness of feedback: The students' perspective. Assessment and Evaluation in Higher Education, 33(2), 143-154.

Price, M., Handley, K., Millar, J., \& O'Donovan, B. (2010). Feedback: All that effort, but what is the effect? Assessment \& Evaluation in Higher Education, 35(3), 277-289.

Pringle, R. M., Dawson, K., \& Adams, T. (2003). Technology, science and preservice teachers: Creating a culture of technology-savvy elementary teachers. Action in Teacher Education, 24(4), 46-52.

Procházka, M., Vítečková, M., \& Žlábková, I. (2015). Änderungen in der staatlichen Abschlussprüfung - Ein Mittel zur Schaffung der beruflichen Identität des Lehrers. In O. Fleischmann, R., Seebauer, \& M., Aleksandrovich (Eds.), The Teaching Profession, Profession Lehrer/in (s. 217-226). Zürich: Lit Verlag.

Raes, A., Vanderhoven, E., \& Schellens, T. (2015). Increasing anonymity in peer assessment by using classroom response technology within face-to-face higher education. Studies in Higher Education, 40(1), 178-193.

Remesh, A. (2013). Microteaching, an efficient technique for learning effective teaching. Journal of Research in Medical Sciences, 18(2), 158-163.

Rokos, L., \& Lišková, J. (2019). Kvalita vrstevnické zpětné vazby při badatelské úloze z biologie člověka v hodinách př́rodopisu. Pedagogická orientace, 29(1), 43-72.

Rokos, L., Vančura, M., \& Procházka, M. (2019). Rozvoj spolupráce mezi učiteli z praxe, studenty učitelství a akademickými pracovníky Pedagogické fakulty Jihočeské univerzity v Českých Budějovicích. In A. Sandanusová \& R. Dytrtová (Eds.), Príprava učitelov prírodovedných, polnohospodárskych a príbuzných oborov v meniacich sa požiadavkách praxe. Sborník př́spěvků z XIII. konference EDUCO 2018 (s. 123-133). Nitra: Univerzita Konštantína Filozofa, Fakulta prírodných vied.

Rotsaert, T., Panadero, E., Estrada, E., \& Schellens, T. (2017). How do students perceive the educational value of peer assessment in relation to its social nature? A survey study in Flanders. Studies in Educational Evaluation, 53(1), 29-40.

Sadler, D. R. (2010). Beyond feedback: Developing student capability in complex appraisal. Assessment \& Evaluation in Higher Education, 35(5), 535-550.

Sivan, A. (2010). The implementation of peer assessment: An action research approach. Assessment in Education, 7(2), 193-213.

Skalková, J. (2007). Obecná didaktika. Praha: Grada.

Sonmez, D., \& Hakverdi-Can, M. (2012). Videos as an instructional tool in pre-service science teacher education. Eurasian Journal of Educational Research, 12(46), 141-158. 
Spilková, V. (1995). Gradace praktické přípravy, reflexivní praxe v novém modelu studia na PedF UK. In kolektiv, Teorie v pedagogické praxi, praxe v pedagogické teorii v učitelském studiu (s. 62-64). Brno: Paido.

Spilková, V. (2004). Současné proměny vzdělávání učitelů. Brno: Paido.

Starý, K., \& Laufková, V. (2016). Formativní hodnocení ve výuce. Praha: Portál.

Star, J. R., \& Strickland, S. K. (2008). Learning to observe: Using video to improve preservice mathematics teachers' ability to notice. Journal of Mathematics Teacher Education, 11(2), 107-125.

Stehlíková, N. (2010). Interpretace některých didakticko-matematických jevů u studentů učitelství a u učitelů matematiky. Pedagogika, 60(3-4), 303-313.

Strijbos, J. W., Narciss, S., \& Dünnebier, K. (2010). Peer feedback content and sender's competence level in academic writing revision tasks: Are they critical for feedback perceptions and efficiency? Learning and Instruction, 20(4), 291-303.

Sucháček, P. (2016). Implementace prvků dialogického vyučování v rámci mikrovyučování u studentů učitelství přírodovědných předmětů. Studia Paedagogica, 21(3), 81-106.

Svatoš, T. (1997a). Od mikrovyučování k mikrovýstupové praxi. Pedagogická orientace, 7(4), 24-28.

Svatoš, T. (1997b). Studentské představy, prožívání a hodnocení učitelské profesionalizace. Pedagogika, 48(2), 150-162.

Šmahelová, B. (2005). Rozvíjení pedagogických dovedností studentů učitelství 1. stupně ZŠ. In R. Jandová (Ed.), Př́íprava učitelů a aktuální proměny v základním vzdělávání (s. 128-133). České Budějovice: Jihočeská univerzita v Českých Budějovicích.

Švaříček, R., \& Šed'ová, K. (Eds.). (2014). Kvalitativní výzkum v pedagogických vědách. Praha: Portál.

Švec, V. (2000). Intervence podporující vytváření didaktických dovedností studentů. In V. Švec \& V. Musil (Eds.), Monitorování a rozvoj pedagogických dovedností (s. 83-104). Brno: Paido.

van Gennip, N. A. E., Segers, M. S. R., \& Tillema, H. H. (2010). Peer assessment as a collaborative learning activity: The role of interpersonal variables and conceptions. Learning and Instruction, 20(4), 280-290.

Vickerman, P. (2009). Student perspectives on formative peer assessment: An attempt to deepen learning? Assessment \& Evaluation in Higher Education, 34(2), 221-230.

Vítečková, M. (2019). Začínající učitel: jeho potřeby a uvádění do praxe. Brno: Paido.

Vondrová, N., \& Žalská, J. (2012). Do student teachers attend to mathematics specific phenomena when observing mathematics teaching on video? Orbis scholae, 6(2), 85-101.

Weaver, M. (2006). Do students value feedback? Students perceptions of tutors' written responses. Assessment and Evaluation in Higher Education, 31(3), 379-394.

Wiliam, D., \& Leahy, S. (2015). Embedding formative assessment: Practical techniques for K-12 classrooms. West Palm Beach: Learning Sciences International.

Yorke, M. (2005a). Formative assessment in higher education. Its significance for employability, and steps towards its enhancement. Tertiary Education an Management, 11(3), 219-238.

Yorke, M. (2005b). Employability in higher education: What it is, what it is not. York: Learning and Teaching Support Network. 
Zhang, M., Lundeberg, M., \& Koehler, M. J. (2015). Affordances and challenges of different types of video for teachers' professional development. In B. Calandra \& P. J. Rich (Eds.), Digital video for teacher education: Research and practice (s. 147-163). Abingdon: Routledge.

Žlábková, I., Procházka, M., \& Vítečková, M. (2016). Inovace pedagogických praxí na PF JU v Českých Budějovicích. In V. Švec, K., Lojdová, \& B., Pravdová (Eds.), Sborník z konference učitelské praxe - současné poznatky a perspektivy (s. 52-58). Brno: Masarykova univerzita.

\section{Autor}

Mgr. Lukáš Rokos, Ph.D., Jihočeská univerzita v Českých Budějovicích, Pedagogická fakulta, Katedra biologie, Jeronýmova 10,371 15 České Budějovice, e-mail: Irokos@pf.jcu.cz

\section{Microteaching as a place for implementation of peer-assessment in the pre-service teacher education}

Abstract: This paper tries to connect two phenomena in teacher education. The first one is the use of microteaching during lessons of subject-specific didactics and the second one is the use of peer-assessment. In total 66 students assessed the microteaching of their peers during lessons of Biology Didactics. They used a structured assessment form with five scale items and three open items. The results showed that student teachers have no problem assessing their peers in scale items but they provided written feedback less willingly. In their feedback, the assessors focus on speech quality, ways of activating and motivating students. Moreover, they pay attention the age appropriateness of the presented activity. The positive finding was the fact that there were no students' personal relationships reflected in the feedback. The formative commentaries were not used very often but when the assessor provided formative feedback, it was correct and helpful for the assessee.

Keywords: microteaching, formative assessment, peer assessment, feedback, teacher education, student teachers 


\section{Příloha}

\section{Hodnocení mikrovýstupů}

Jméno vyučujícího studenta:

Zaměření mikrovýstupu:

Název mikrovýstupu:

Ohodnot’te jednotlivé položky na škále od 1 do 10 (10 - nejlepší).

1. Atraktivita (např. aktivizace žáků, motivační prvky)

2. Zpracování (např. adekvátnost věku, názornost)

3. Správnost (např. věcná správnost)

4. Kvalita projevu (např. logika mluveného slova, vyjadřování se)

5. Využitelnost v praxi

Silné stránky:

Slabé stránky:

Navržené změny: 